\title{
Startups' Valuation: A Bibliometric Analysis and Systematic Literature Review
}

\author{
William Aparecido Maciel Da Silva, Cristiane Orquisa Fantin, Marcelo Fukui, \\ Michele Nascimento Jucá \\ Mackenzie Presbiterian University, São Paulo, Brazil \\ Email: w.aparecidomaciel@hotmail.com,cris.orquisa@hotmail.com, marcelofukui@gmail.com,michele.juca@mackenzie.br
}

How to cite this paper: Da Silva, W. A. M., Fantin, C. O., Fukui, M., \& Jucá, M. N. (2021). Startups' Valuation: A Bibliometric Analysis and Systematic Literature Review. Open Journal of Business and Management, 9, 1647-1670.

https://doi.org/10.4236/ojbm.2021.94090

Received: May 18, 2021

Accepted: July 10, 2021

Published: July 13, 2021

Copyright ( 2021 by author(s) and Scientific Research Publishing Inc. This work is licensed under the Creative Commons Attribution International License (CC BY 4.0).

http://creativecommons.org/licenses/by/4.0/

\begin{abstract}
This study maps and analyzes the academic literature regarding the main startups' valuation methods by means of a bibliometric analysis and systematic review. The adoption of both methods requires the use of software such as RStudio, VOSViewer or Rank Words. In bibliometric analysis, the verification of its main laws-Zipf, Bradford and Lotka is also adopted. As a bibliometric analysis result, the most frequent keywords appear to be performance, innovation, entrepreneurship and venture capital. Most of the authors are associated with institutions located in Germany and in the United States. Concerning the systematic review results, the topic of identifying funding sources is urgent, considering the fact that startups are companies with high levels of uncertainty and risk. Another concern refers to the way of obtaining the types of data for inputs in the valuation models. Regarding the valuation methods, the ones of multiples are highlighted. As for future paths for further research, the authors emphasize the analysis of determinants influencing their value at different stages of maturity, as well as the adoption of unconventional valuation methods.
\end{abstract}

\section{Keywords}

Valuation, Startups, Bibliometric Analysis, Systematic Review

\section{Introduction}

Providers of innovation and economic growth, startups (SUs) are necessary for the process of market creative destruction. As they enter it, they replace old and stagnant companies (Laitinen, 2019). Thus, these newly born companies offer the market innovative products or services with growth potential-even if they do so under extreme uncertainty conditions. In their initial phase, SUs show 
negative results due to little or no revenue earned. Therefore, their evolution to scaleups depends on the correctness of their strategic decisions-choice of suppliers, necessary incentives to attract investors and a qualified team to manage the tasks. Despite their diversity, these companies have characteristics in common, such as: 1) they have no accounting or financial historical reference; 2) equity dependence; 3) high failure probability, especially in their early stages; 4) low liquidity; 5) high concentration of intangible assets; 6) uniqueness in the context of their comparison with other companies; 7) focus on management quality (Gavious \& Schwartz, 2011; Glaveckaite, 2020).

Given the inexistence or low level of assets and revenues, SUs have difficulties in raising funds from third parties. Thus, their initial financing is usually through equity - crowdfundings, venture capital funds (VC) and private equity (PE). Another obstacle observed refers to their valuation, which-according to Mirzanti, Sinaga and Soekarno (2019) - is not based only on financial features, but also on subjective judgments. As they have no history, their equity value is irrelevant. Estimating their relative value does not require the existence of comparable companies, which is difficult to identify due to their innovative character. There is no capitalization value. Finally, the application of the discounted cash flow method is not very accurate due to the uncertainties about their growth projection, calculation of the equity cost-and the consequent discount rate, as well as to the definition of scenarios. So, assigning value to SUs is a difficult task and subject to inaccuracies, which makes this process even more relevant.

The informational asymmetry between SUs' founders and investors may generate an opportunistic behavior by their creators-adverse selection (hidden information) and moral risk (hidden actions). Therefore, adopting corporate governance mechanisms is necessary, although this is only feasible when the company has a relevant data history. Among these mechanisms is the preparation and monitoring of the commitment term signed between the parties. If it is not well prepared and fulfilled, this fact may cause interest conflicts, dissatisfaction, investment loss, takeover, implementation of collateral and-ultimately, contract breach by the parties. These peculiarities make the process of valuation SUs even more difficult (Festel, Wuermseher, \& Cattaneo, 2013; Amalian \& Amalyan, 2018).

This being so, the objective of this study is to map and to analyze the academic literature published regarding the main SUs' valuation methods. To this end, a bibliometric analysis and systematic literature review on the theme is performed -from 1945 to October, 17th, 2020-for a final sample of 20 articles. The former refers to a quantitative analysis, developed by counting frequencies and co-citations. The latter refers to a qualitative analysis, looking for the correlation between relevant themes, however, still little explored by the academy. The search for articles is obtained from the Web of Science (WoS) database. The adoption of both methods requires the use of software such as RStudio, VOSViewer or Rank Words. In bibliometric analysis, the verification of its main laws, 
such as Zipf (1949), Bradford (1934) and Lotka (1926) is also adopted.

In item 2 of this study, the literature review is presented, with identification of the theories and methods for valuating SUs-mentioned in the papers of the final sample. In item 3, the methodologies of bibliometric analysis and systematic review are described. In item 4, the results of both methodologies are reported, with identification of the descriptive statistics of the main characteristics of the final sample papers, as well as of the knowledge gaps on the subject. Finally, in item 5 , the conclusions, paths for future studies and limitations of this research are exposed.

\section{Literature Review}

The growing role that SUs play in the economy stimulates the development of research aimed at building theories, involving the innovation and entrepreneurship themes (Joglekar \& Lévesque, 2009). According to Masulis and Nahata (2009), the increase in the volume of investments in SUs by VC funds is mainly due to the strategic benefits resulting from their capacity for innovation in already consolidated markets.

Regarding the valuation of SUs, for Audretsch and Link (2012), the traditional valuation methods of consolidated companies are questionable when applied to them. In addition, there is a lack of adequate and sufficient financial information to make this process feasible. Such facts make estimating their value a challenging task (Yoo, Yang, Kim, \& Heo, 2012). Furthermore, SUs have a high volume of intangible assets, which makes it difficult to valuate them by using generally accepted accounting principles.

According to the International Accounting Standards (IAS 38, 2004) and International Financial Reporting Standards (IFRS 3, 2008), accounting for intangible assets is possible as long as they are identifiable, controlled and generators of future economic benefits. However, different aspects of this description are not accounted for-ex: brand valuation, board's management capacity, etc. In addition, SUs are in the early stage of their life cycle (Gavious \& Schwartz, 2011).

In turn, SUs' revenues are small or zero, which generates negative operating results. Thus, estimates of their cash flow, discount rate and growth results in distorted values. Comparable companies cannot be used as a parameter either, since SUs are based on innovative and disruptive businesses (Davila, Foster, \& Jia, 2015; Dhochak \& Doliya, 2020).

Thus, in the SUs' valuation process, a good information quality substantially reduces potential conflicts between entrepreneurs and investors. Informational asymmetry influences investors' decisions, the proportion of capital invested, the potential for profitability and the motivation for the entrepreneur to work his idea in a committed and dedicated way (Zacharakis, Erikson, \& George, 2010).

As an alternative to traditional financial information, Sievers, Mokwa and Keienburg (2013) point to the relevance of considering non-financial informa- 
tion for their valuation-which are performance proxies-e.g.: relationship network capillarity, quality of internal resources, expansion of number of employees, team experience, number of patents, business characteristics, number of fundraising rounds, annual contributions by VC funds, etc.

For Hsu (2007), Davila et al. (2015) and Dhochak and Doliya (2020), the most relevant criterion in a SU's valuation process is its internal resources-entrepreneur's history and experience, quality of leadership, of management team and of founders. According to Wasserman (2017), the founder's vision and skills are relevant determinants in determining the SUs' value, in their initial phase. However, his permanence as main manager tends to negatively impact the company's value in later stages.

In a SUs' valuation process, the signaling theory states that activities or attributes related to corporate governance may be used as sources of information and have the potential to affect investors' expectations and perceptions. The signals help the receiver to form an opinion about an unobservable or difficult to perceive indicator. For the signal to have informational value, it needs to have two features-it must be observable and its acquisition cost must be compensated for the quality provided (Block, De Vries, Schumann, \& Sandner, 2014).

In this sense, Fitza and Dean (2016) suggest that VC funds impact the pricing of SUs' shares at the time of their Initial Public Offering (IPO). For the authors, this is because VC funds have a better capacity for valuating companies and signaling their quality to the market. However, their reputation may be damaged in case they submit a low quality SU to this process. For Vaidyanathan, Vaidyanathan and Wadhwa (2019), VC funds not only finance SUs, but also offer their expertise in management, innovation and strategic vision.

Another SUs' relevant funding source is the direct raising of own resources from third parties-equity crowdfunding (Kleinert \& Volkmann, 2019). In this process, the difference between the volume of funds raised in the pre-money valuation (first round) and post-money valuation (second round) determines the investors' return expectation on the project. Hornuf and Neuenkirch (2017) find that reaching the fundraising goal raises the SU's value. The determination of the volume of resources to be raised in the pre-money valuation occurs in the initial stages of the process (Berger \& Kohn, 2018).

Valuation processes are theoretical introductions to a game of supply and demand. Investors see the SUs' long-term potential-and not just possible shortterm benefits. Thus, the value attributed to the company is defined by the contraposition between the entrepreneur's intentions and objectives versus his ability to generate future value. Based on the assumptions of the game theory, investors pursue rational goals and consider this very expectation in relation to others. Game theory may also be integrated with real options, in order to analyze the flexible decisions of irreversible investments in risk conditions. One objective of this approach to game theory of real options is to optimize a trade-off 
between waiting for the reduction of uncertainties and an eventual value to be obtained in the investment decision (Fujikawa, 2014).

The SUs' creation and enhancement are also affected by the institutional environment in which they are inserted. Thus, countries with efficient institutions, high levels of innovation and potential markets are more conducive to the development of these companies (Berger \& Kohn, 2018). When analyzing Chinese unicorns-companies reaching a market value over US\$ 1 billion-Zhai and Carrick (2019) identify other relevant characteristics, among them: existence of well-defined processes for organizational learning, their founders' scientific and management skills and strategic alliances with investors to raise funds on a recurring basis.

Another aspect to be highlighted is the impact of economic theory on the size and markets in which companies operate. Small companies have fewer resources than large ones. However, small companies-which operate in international markets-foresee their cash flows better than those operating only in domestic markets. This way, the former present higher levels of technical productive efficiency (Baek \& Neymotin, 2016).

\section{Methodology}

The purpose of this study is to answer the question - what are the main methods of startups valuation? To this end, the 7 steps described below are implemented. Steps 1 to 5 address both bibliometric analysis and systematic review methodologies. Yet, steps 6 and 7 refer exclusively to systematic review.

Step 1-Database choice. The sample articles are obtained from WoS, which is the world leading database of citations. It contains records of papers published in high impact factor scientific journals, being classified by the Journal Citation Reports (JCR).

Step 2-Use of initial search parameters from the WoS. For the period from January 1st, 1945 to October, 17th, 2020, 160 articles are initially identified based on variations of the keywords Valuation and Startup. Subsequently, exclusions are made through the application of filters in the WoS itself, resulting in an intermediate sample of 78 papers, as shown in Figure 1.

Step 3-Exclusion of unrelated papers. After the initial reading of the abstract, introduction and conclusion of the articles-to verify whether they are in accordance with the defined theme- 58 from 78 articles in the intermediate sample are excluded. The main reasons for their exclusion are: a) 24 papers on business management; b) 26 papers on other topics not related to valuation-e.g.: investment opportunity, project management and financing decisions; and c) 8 papers on valuation of companies other than SUs-e.g.: IPOs, M\&A and synergy. Thus, the final sample consists of 20 papers. Consequently, the results presented in item 4. Analysis of the results-are limited to the selection criteria of the final sample, as mentioned in steps 2 and 3. 


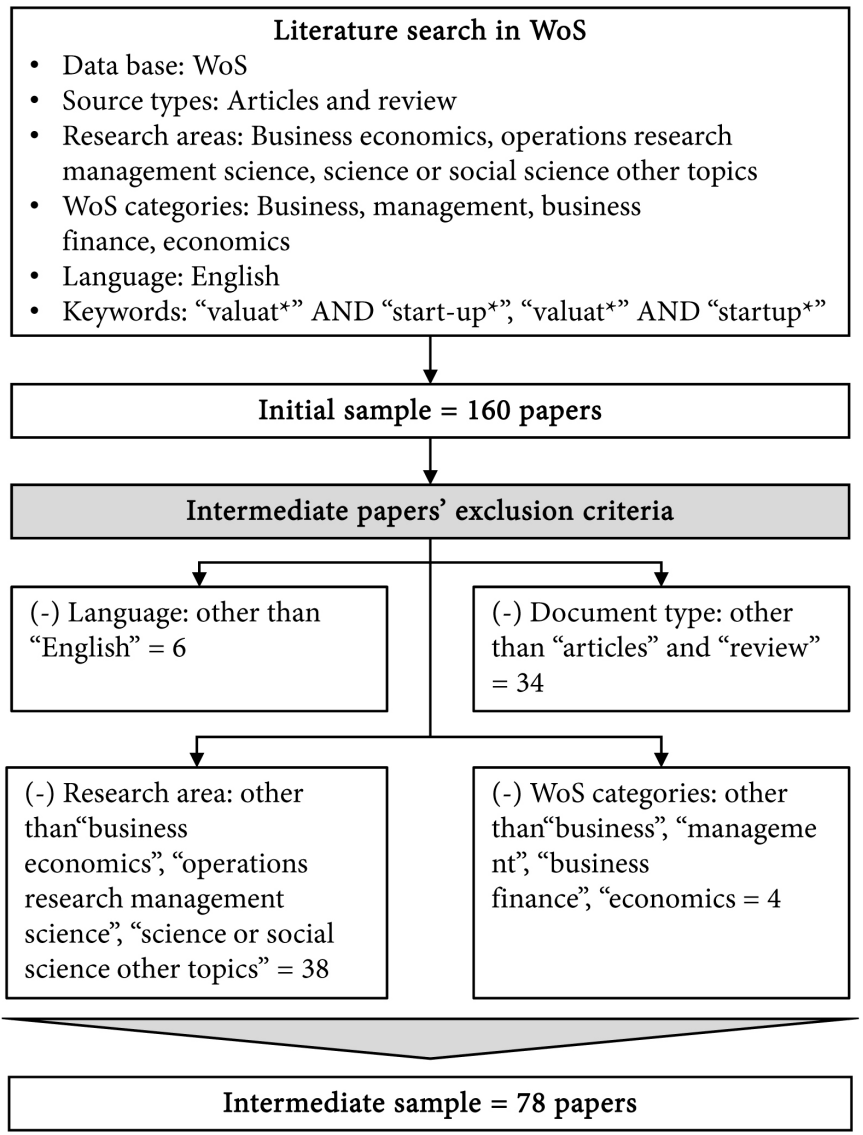

Figure 1. Sample evolution by using WoS’ filters.

Step 4-Creation of a database and collection of papers. The 20 articles in the final sample are obtained from the following academic research bases: (4) Science Direct, (12) Web of Science and (4) Taylor \& Francis. From their analysis, the following information is collected to capture the paper general data: title, author's name, affiliated institution and authors/researchers' country of origin, name of the journal, volume and issue number, initial page and final page, year of publication, country of data source and number of years of sample data, keywords, Digital Object Identifier (DOI), Journal of Economic Literature (JEL) and number of article citations in the WoS database.

Step 5-Bibliometric analysis. Through the software RStudio, Biblioshiny and VOSviewer, objective data of the articles-countries, authors, keywords, institutions, etc. are analyzed-for the elaboration and analysis of tables and maps of relationship/cocitation. The analyses performed by both tools are complemented by the verification of the main laws of bibliometrics, being: 1) Zipf's Law (1949)categorization and estimation of the keywords frequency, with the aid of Rank Words software to calculate Goffman's T point-transition point from low to high frequency words, a region that theoretically concentrates words with a high semantic load, 2) Bradford's Law (1934)—verification of journals producing many articles in contrast of those producing few on a given topic, and 3) Lotka's 
Law (1926) - identification of researchers having a higher production frequency in a given knowledge area.

Step 6-Reading and coding the articles. Identification of the objectives, sample, methods and contributions of the articles. In addition, they are classified and coded into categories and subcategories structured according to Table 1. Each of the 10 categories has non-exclusive subcategories. This means that, the same article can be classified into more than one subcategory. Thus, the sum of the frequency count of the subcategories-for each category-is the one that totals $100 \%$. In the codification process, up to 3 subcategories per article are assigned to each category.

Step 7-Systematic review. After coding the (sub) categorization matrix in Table 1 -for the final sample-a frequency count of the subcategories is performed to enable the identification of knowledge gaps. Such gaps are then compared with the subcategories of category 10 - paths for future studies, in order to obtain aspects that may be subject to further studies on the subject.

In summary, the systematic review is a method used to evaluate a set of data from different studies. It seeks to collect all empirical evidence that fits pre-defined eligibility criteria, in order to answer a specific question. In addition, it uses systematic methods that are selected in order to minimize bias. Thus, the systematic review contributes to offer more reliable results, with which conclusions and decisions can be made and knowledge gaps are identified.

\section{Analysis of the Results}

Item 5.1 presents the bibliometric analysis results, mentioned in Step 5 of the Methodology. In turn, item 5.2 contains the systematic review results, the steps of which are described in Steps 6 and 7 of item 3 of this study.

\subsection{Bibliometric Analysis}

The final sample consists of 20 articles, distributed between the years 2007 and 2020, obtained from the WoS database-see Figure 2. During this period, from 1 to 2 articles on SUs' valuation per year are identified.

Table 2 presents the frequency of the 10 main keywords of the study, highlighting performance (26.09\%), innovation (13.04\%) and companies (10.87\%). Such words can also be seen in Figure 3.

Figure 3 shows the map of co-occurrences of the most used keywords in the papers. Again, the words performance and innovation, in addition to entrepreneurship and venture capital stand out.

Still on keywords, the Zipf Law (1949) indicates that there is an optimization in their use. Thus, they do not disperse. On the contrary, there is a tendency for minimal use of keywords, with a high frequency of occurrence. Zipf's first law states that, the product of the series $(r)$ of a word by the order of its frequency of occurrence $(f)$ is approximately constant $(C)$, resulting in Equation (1):

$$
r \times f=C
$$


Table 1. Matrix of (sub) categorization.

\begin{tabular}{|c|c|c|}
\hline Categories & Subcategories & Definition \\
\hline \multirow{6}{*}{$\begin{array}{l}\text { 1. Main theme/study } \\
\text { focus }\end{array}$} & A-Valuation of SUs & $\begin{array}{l}\text { Methods and main aspects related to } \\
\text { the SUs' valuation process. }\end{array}$ \\
\hline & B-Entrepreneurship & $\begin{array}{l}\text { Initiative to implement new businesses } \\
\text { or changes in existing companies, with } \\
\text { changes involving innovation and risks. }\end{array}$ \\
\hline & $\mathrm{C}$-Venture capital & $\begin{array}{l}\text { Investment in companies having high } \\
\text { growth potential, with direct influence } \\
\text { on their management, contributing to } \\
\text { the value creation for future sale of } \\
\text { shareholding in the company. }\end{array}$ \\
\hline & D-Uncertainties and risks & $\begin{array}{l}\text { Risk is the ability to measure the } \\
\text { uncertainty of a decision, by knowing } \\
\text { the probabilities of the occurrence of } \\
\text { certain results. }\end{array}$ \\
\hline & E-Funding ways & $\begin{array}{l}\text { Source of fundraising through equity } \\
\text { and third parties'. }\end{array}$ \\
\hline & F-Others & $\begin{array}{l}\text { Other topics not related to } \\
\text { subcategories } 1 \mathrm{~A} \text { to } 1 \mathrm{E} \text {. }\end{array}$ \\
\hline
\end{tabular}

\begin{tabular}{|c|c|c|}
\hline \multirow{4}{*}{$\begin{array}{l}\text { 2. Theories related } \\
\text { to the study objective }\end{array}$} & A-Signaling & $\begin{array}{l}\text { asymmetry theory, with the signals } \\
\text { helping the less informed party to } \\
\text { make decisions. }\end{array}$ \\
\hline & B-Games & $\begin{array}{l}\text { It deals with the interaction between } \\
\text { participants. The decisions of one } \\
\text { depend on the actions of the other. }\end{array}$ \\
\hline & C-Others & $\begin{array}{l}\text { Other theories not related to } \\
\text { subcategories } 2 \mathrm{~A} \text { to } 2 \mathrm{~B} \text {. }\end{array}$ \\
\hline & D-With no theory & $\begin{array}{l}\text { There is no identification of theories } \\
\text { supporting the study objective. }\end{array}$ \\
\hline \multirow{4}{*}{$\begin{array}{l}\text { 3. Research } \\
\text { methods }\end{array}$} & $\begin{array}{l}\text { A-Application of } \\
\text { questionnaires }\end{array}$ & $\begin{array}{l}\text { Data obtained from questionnaire } \\
\text { responses. }\end{array}$ \\
\hline & B-Econometric models & Use of econometric regression equations. \\
\hline & C-Case study & $\begin{array}{l}\text { Empirical research strategy used to } \\
\text { investigate a recent phenomenon and } \\
\text { that enables the explanation of causal } \\
\text { links of singular situations. }\end{array}$ \\
\hline & D-Others & $\begin{array}{l}\text { Other methods not related to } \\
\text { subcategories } 3 \mathrm{~A} \text { to } 3 \mathrm{C} \text {. }\end{array}$ \\
\hline \multirow{3}{*}{$\begin{array}{l}\text { 4. Valuation } \\
\text { methods }\end{array}$} & A-Discounted cash flow & $\begin{array}{l}\text { Present value of future cash flows } \\
\text { discounted at a rate reflecting the risk } \\
\text { of the company or its owners. }\end{array}$ \\
\hline & B-Multiples & $\begin{array}{l}\text { They derive from the pricing of similar } \\
\text { assets standardized by a common variable. }\end{array}$ \\
\hline & C-Equity & $\begin{array}{l}\text { Book value of the difference between the } \\
\text { company's assets/rights and obligations. }\end{array}$ \\
\hline
\end{tabular}




\section{Continued}

\begin{tabular}{|c|c|c|}
\hline & D-Real options & $\begin{array}{l}\text { Common and preferred shares are } \\
\text { considered call options on the company's } \\
\text { value. In this way, the investor has the } \\
\text { right, but not the obligation, to acquire } \\
\text { the company's residual value at a certain } \\
\text { price and on a certain date. }\end{array}$ \\
\hline & E-Others & $\begin{array}{l}\text { Other valuation methodologies of } \\
\text { companies, not related to subcategories } \\
4 \text { A to } 4 \mathrm{D} \text {. }\end{array}$ \\
\hline \multirow{7}{*}{$\begin{array}{l}\text { 5. Valuation } \\
\text { model inputs }\end{array}$} & A-Innovation capacity & $\begin{array}{l}\text { SUs' capacity to transform resources } \\
\text { into innovations in a systemic way. }\end{array}$ \\
\hline & B-Internal resources & $\begin{array}{l}\text { Information, knowledge, skills and } \\
\text { experiences available to SUs. }\end{array}$ \\
\hline & C-External links & $\begin{array}{l}\text { Relationship network supporting SUs } \\
\text { to increase their growth prospects. }\end{array}$ \\
\hline & D-Competitive advantages & $\begin{array}{l}\text { Development of new products, market } \\
\text { perception and differentiation in } \\
\text { relation to competitors. }\end{array}$ \\
\hline & $\begin{array}{l}\text { E-Management/accounting } \\
\text { information }\end{array}$ & $\begin{array}{l}\text { Obtained from standard reports and } \\
\text { which may serve as inputs to measure } \\
\text { the SUs' value. }\end{array}$ \\
\hline & F-Others & $\begin{array}{l}\text { Other inputs not related to } \\
\text { subcategories } 5 \mathrm{~A} \text { to } 5 \mathrm{E} \text {. }\end{array}$ \\
\hline & G-With no information & $\begin{array}{l}\text { There is no identification of information } \\
\text { that may be considered as inputs to the } \\
\text { valuation models. }\end{array}$ \\
\hline \multirow{4}{*}{ 6. Data type } & A-Financial statements & $\begin{array}{l}\text { Periodic financial accounting data that } \\
\text { represent the companies' equity and } \\
\text { income. }\end{array}$ \\
\hline & B-Regulatory bodies & $\begin{array}{l}\text { Public data of companies made available } \\
\text { by the market and the regulatory } \\
\text { bodies-e.g.: relevant facts. }\end{array}$ \\
\hline & C-Questionnaires & $\begin{array}{l}\text { Primary data obtained through a } \\
\text { survey of respondents. }\end{array}$ \\
\hline & D-Others & $\begin{array}{l}\text { Other data not related to subcategories } \\
6 \mathrm{~A} \text { to } 6 \mathrm{C} \text {. }\end{array}$ \\
\hline \multirow{3}{*}{ 7. Data source } & A-Developed country & $\begin{array}{l}\text { Country with annual per capita income } \\
\text { as of US\$12,376 (World Bank, 2019). }\end{array}$ \\
\hline & $\begin{array}{l}\text { B-Undeveloped/emerging } \\
\text { country }\end{array}$ & $\begin{array}{l}\text { Country with annual per capita income: } \\
\text { Low—less than US } \$ 1025 \text {; Low } \\
\text { Medium-between US } \$ 1026 \text { and } \\
\text { US } \$ 3995 \text {; and High Medium—between } \\
\text { US } \$ 3996 \text { and US } \$ 12,375 \\
\text { (World Bank, 2019). }\end{array}$ \\
\hline & C-Both & $\begin{array}{l}\text { Includes all countries, developed and } \\
\text { undeveloped. }\end{array}$ \\
\hline \multirow{2}{*}{ 8. Analysis period } & A-up to 5 years & Data from 0 to 5 years. \\
\hline & B-From 6 to 10 years & Data from 6 to 10 years. \\
\hline
\end{tabular}




\section{Continued}

\begin{tabular}{|c|c|c|}
\hline & $\mathrm{C}$-More than 10 years & Over 10 years. \\
\hline & $\begin{array}{l}\text { D-Not applicable/not } \\
\text { informed }\end{array}$ & $\begin{array}{l}\text { Studies that do not inform the period of } \\
\text { analysis. }\end{array}$ \\
\hline \multirow{4}{*}{ 9. Results } & A-New perspectives & $\begin{array}{l}\text { Presentation of a new theory, } \\
\text { variable/proxy or SUs' valuation method. }\end{array}$ \\
\hline & B-New conclusions & $\begin{array}{l}\text { Presentation of new } \\
\text { conclusions-adjustments in traditional } \\
\text { valuation models, entrepreneur's } \\
\text { influence, private information quality, } \\
\text { importance of innovative capacity and } \\
\text { of external networks, etc. }\end{array}$ \\
\hline & $\begin{array}{l}\text { C-Conclusions similar to } \\
\text { previously presented works }\end{array}$ & $\begin{array}{l}\text { Studies presenting neither new } \\
\text { perspectives nor new conclusions. }\end{array}$ \\
\hline & D-Others & $\begin{array}{l}\text { Other results not related to subcategories } \\
9 \mathrm{~A} \text { to } 9 \mathrm{C} \text {. }\end{array}$ \\
\hline \multirow{6}{*}{$\begin{array}{l}\text { 10. Paths for } \\
\text { future studies }\end{array}$} & A-Stages of development & $\begin{array}{l}\text { Valuation of SUs at different stages of } \\
\text { development. }\end{array}$ \\
\hline & B-Cultural differences & $\begin{array}{l}\text { Analysis of the impact of cultural } \\
\text { differences on the SUs' value. }\end{array}$ \\
\hline & $\mathrm{C}-$ Valuation of intangibles & $\begin{array}{l}\text { Verification of the impact of brands and } \\
\text { patents on the SUs' value. }\end{array}$ \\
\hline & D-Organizational growth & $\begin{array}{l}\text { Examination of the organizational growth } \\
\text { dynamism effects on the SUs' value. }\end{array}$ \\
\hline & $\begin{array}{l}\text { E-Other SUs' valuation } \\
\text { methods }\end{array}$ & $\begin{array}{l}\text { Adoption of non-conventional company } \\
\text { valuation methods for SUs-e.g.: } \\
\text { First Chicago, Scorecard, } \\
\text { Venture Capital, Berkus, etc. }\end{array}$ \\
\hline & $\begin{array}{l}\text { F-No path commented on } \\
\text { by the author (s) }\end{array}$ & No future path detailed by the author (s). \\
\hline
\end{tabular}

Table 2. Keywords.

\begin{tabular}{ccc}
\hline Keywords & Quantity & Frequency $\%$ \\
\hline Performance & 12 & $26.09 \%$ \\
Innovation & 6 & $13.04 \%$ \\
Firms & 5 & $10.87 \%$ \\
Entrepreneurship & 4 & $8.70 \%$ \\
Information & 4 & $8.70 \%$ \\
Empirical-analysis & 3 & $6.52 \%$ \\
Market & 3 & $6.52 \%$ \\
Model & 3 & $6.52 \%$ \\
Private equity & 3 & $6.52 \%$ \\
Research-and-development & 3 & $6.52 \%$ \\
Total & 46 & $100 \%$
\end{tabular}




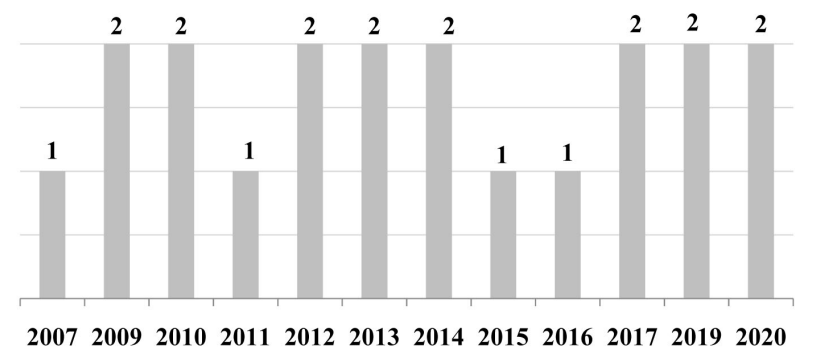

Figure 2. Annual distribution of papers.

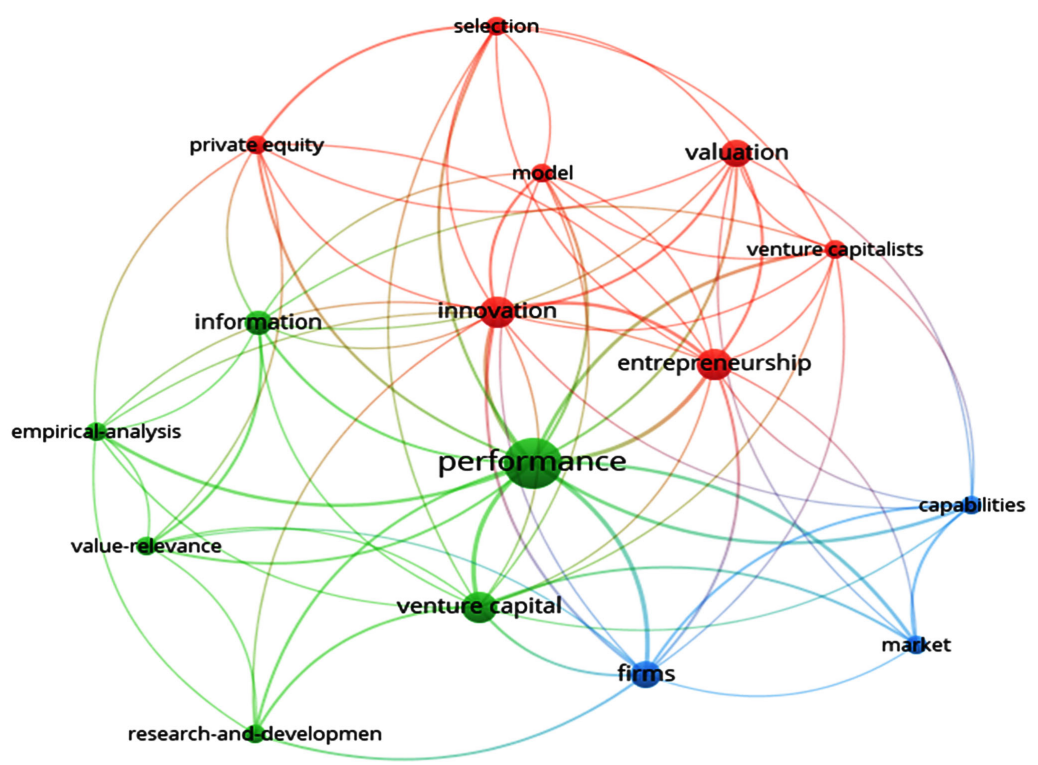

Figure 3. Keywords co-occurrence map. Source: VOSviewer. Note: The size of the nodes represents the relevance of the terms in the papers. The thickness of the lines means the bonding force between them. Finally, the colors indicate the number of groups.

For low-frequency words, Zipf proposed a second law, which was revised and modified by Booth (1967). According to the author, in a given text, several words with low frequency of occurrence have the same assiduity-see Equation (2):

$$
I_{n}=2 I_{1} / n(n+1)
$$

In which:

$I_{1}=$ number of words with frequency 1 ,

$I_{n}=$ number of words with frequency $n$,

$n=$ Goffman's point or place of transition from low to high frequency words.

Zipf's laws define the extremities of a word distribution list. Between these extreme points, there is a transition region from high to low frequency words. According to Goffman (1971), in this region are the words with the highest semantic content, being the most suitable for the thematic indexing of a given text. Pao (1978) presents the formula for Goffman's T-point or transition point-see Equation (3). 


$$
T=\left(-1+\sqrt{1+8 I_{1}}\right) / 2
$$

In which:

$T=$ Goffman's transition point,

$I_{1}=$ number of words with frequency 1 .

The identification of Goffman's T-point occurs through decreasing ordering of words by the Rank Words software. In the sequence, those that are repeated only once, for the calculation of Goffman's T-point, are identified. Then, those words above the classification indicated by that point are located. Table 3 indicates that-for the 20 articles in the final sample-the transition point from low to high frequency words varies between 33.03 and 47.08 , with an average of 39.79 .

Then, an analysis is done of the region in which there are the most related words to the main theme of the text. So, those that are not relevant to the study are excluded-e.g.: prepositions, (in) definite articles, pronouns and adverbs. Then, the words having the most frequency are classified, as shown in Table 4.

Table 3. Goffman's T-point.

\begin{tabular}{|c|c|}
\hline Reference & Goffman's T-point \\
\hline Wasserman (2017) & 47.08 \\
\hline Zheng, Liu and George (2010) & 46.11 \\
\hline Hsu (2007) & 45.28 \\
\hline Joglekar and Levesque (2009) & 44.00 \\
\hline Sievers et al. (2013) & 43.25 \\
\hline Masulis and Nahata (2009) & 42.35 \\
\hline Kleinert and Volkmann (2019) & 41.17 \\
\hline Dhochak and Doliya (2020) & 39.75 \\
\hline Becker et al. (2016) & 39.73 \\
\hline Ivanov and Xie (2010) & 39.63 \\
\hline Block et al. (2014) & 39.48 \\
\hline Hornuf and Neuenkirch (2017) & 39.30 \\
\hline Zhai and Carrick (2019) & 38.77 \\
\hline Greenberg (2013) & 38.49 \\
\hline Fujikawa (2014) & 37.13 \\
\hline Berger and Kohn (2018) & 37.05 \\
\hline Davila et al. (2015) & 35.48 \\
\hline Yoo et al. (2012) & 35.17 \\
\hline Gavious and Schwartz (2011) & 33.53 \\
\hline Audretsch and Link (2012) & 33.03 \\
\hline Average & 39.79 \\
\hline
\end{tabular}


Table 4. Word classification-Zipf law.

\begin{tabular}{|c|c|c|c|}
\hline References & Words & Quantity & Frequency $\%$ \\
\hline Masulis and Nahata (2009) & start-up & 407 & $12.27 \%$ \\
\hline Block et al. (2014) & start-up & 333 & $10.04 \%$ \\
\hline Greenberg (2013) & patent & 234 & $7.06 \%$ \\
\hline Wasserman (2017) & control & 228 & $6.88 \%$ \\
\hline Sievers et al. (2013) & financial & 200 & $6.03 \%$ \\
\hline Hsu (2007) & capital & 197 & $5.94 \%$ \\
\hline Kleinert and Volkmann (2019) & investors & 180 & $5.43 \%$ \\
\hline Davila et al. (2015) & valuation & 176 & $5.31 \%$ \\
\hline Zheng et al. (2010) & firm & 169 & $5.10 \%$ \\
\hline Berger and Kohn 2018 & valuation & 156 & $4.70 \%$ \\
\hline Dhochak and Doliya, 2020 & venture & 147 & $4.43 \%$ \\
\hline Yoo et al. (2012) & industry & 128 & $3.86 \%$ \\
\hline Ivanov and Xie (2010) & strategic & 120 & $3.62 \%$ \\
\hline Gavious and Schwartz (2011) & value & 106 & $3.20 \%$ \\
\hline Becker et al. (2016) & start-up & 103 & $3.11 \%$ \\
\hline Hornuf and Neuenkirch (2017) & funding & 103 & $3.11 \%$ \\
\hline Zhai and Carrick (2019) & firms & 102 & $3.08 \%$ \\
\hline Fujikawa (2014) & biotech & 88 & $2.65 \%$ \\
\hline Joglekar and Levesque (2009) & capital & 88 & $2.65 \%$ \\
\hline Audretsch and Link (2012) & entrepreneurial & 51 & $1.54 \%$ \\
\hline Total & & 3,316 & $100.00 \%$ \\
\hline
\end{tabular}

In the paper by Masulis and Nahata (2009), the word Start-up has the highest frequency, being repeated 407 times in a text with 21,873 words. However, in the total of 3316 words with the highest frequency, it represents $25.42 \%$, standing out in 3 of the 20 papers in the final sample.

As for the authorship of the papers, 44 authors are identified. Out of these, 4 publish individually and 40 are co-authors. Figure 4 shows the ranking in descending order of the 8 countries of the institutions with which the authors are associated. Of the 44 authors, $16(36.4 \%)$ are associated with institutions located in Germany, 13 (29.5\%) in the United States, 4 (9.1\%) in South Korea, 3 (6.8\%) in China, 3 (6.8\%) in Israel, 2 (4.5\%) in Canada, 2 (4.5\%) in India and 1 (2.3\%) in Japan. According to RStudio software, out of the 20 papers, 15 (75\%) are classified as single country publications (SCP) - papers written by authors associated with institutions in the same country-and 5 (25\%) are multiple country publications (MCP) - papers written by authors associated with institutions in different countries. 


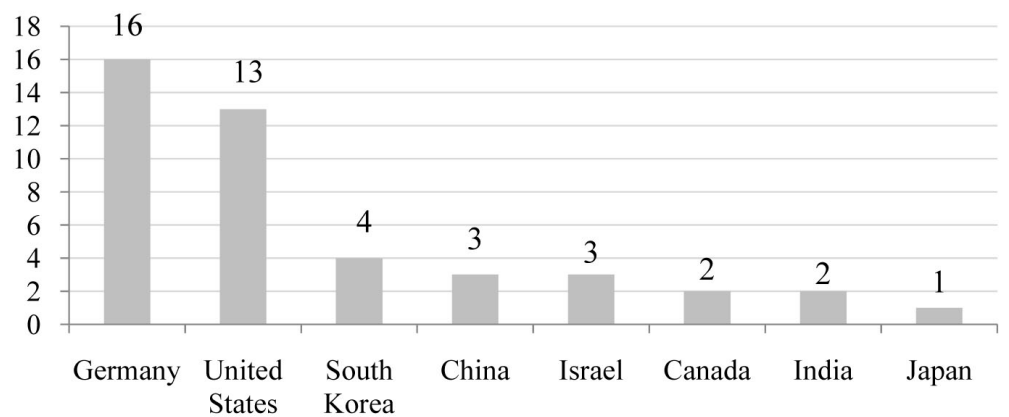

Figure 4. Frequency of papers from the countries of the institutions with which the authors are associated.

Figure 5 indicates that 397 (67.4\%) citations are of papers written by authors associated with institutions located in the United States. The remaining citations are by authors who are linked to institutions in the following countries: Germany 89 (15.1\%), United Kingdom 53 (9.0\%), Israel 24 (4.1\%), China 16 (2.7\%), South Korea $6(1.0 \%)$ and Japan $4(0.7 \%)$.

Table 5 indicates the journals in which the 20 papers of the final sample are published, through the application of Bradford's Law (1934). The law states that there are few journals producing many articles and many journals producing few articles on a given topic. For Brookes (1969), this law estimates the relevance degree of certain academic journals that work in specific knowledge areas. Thus, if journals are classified in a decreasing productivity order, they may be distributed in zones having a variation in the proportion $1: \mathrm{n}: \mathrm{n}^{2}$, and so on.

These zones are formed by dividing the total number of published papers by two. Zone A is identified as the core of the subjects, being made up of journals with two references, highlighting the European Accounting Review, Journal of Business Venturing and Small Business Economic. Zone B, on the other hand, presents journals with only a single publication.

Figure 6 shows the co-citation network among the journals in the 20-paper final sample. The most cited are Journal of Business Venturing, Journal of Financial Intermediation, Strategic Management Journal. Out of these 3, only the Journal of Business Venturing stands out in Table 5. This fact indicates that, not necessarily the journals that most publish on a given topic are the most cited, characterizing the relevance of the papers.

Table 6 presents the ten most cited papers on the topic of SUs' valuation. Among them, the paper by Hsu (2007) stands out with 256 (46.8\%) of the citations and an annual average of 17.07. The paper analyzes the variation of sources and the valuation of VC funds among entrepreneurs, based on their previous experience with SU, academic education and social networks. The second and third most cited papers are those by Zheng et al. (2010) and Ivanov and Xie (2010) with 53 citations and an annual average of 4.

In turn, Lotka (1926) states that a small number of authors produce many papers and that the production obtained by this small number of researchers is 
Table 5. Bradford's law on journals.

\begin{tabular}{|c|c|c|c|c|}
\hline Zone & Journals & $\begin{array}{l}\text { Individual } \\
\text { quantity }\end{array}$ & $\begin{array}{c}\text { Accumulated } \\
\text { quantity }\end{array}$ & $\begin{array}{c}\text { Accumulation } \\
\text { percentage }\end{array}$ \\
\hline \multirow{3}{*}{ Zone A } & European Accounting Review & 2 & 2 & $10.0 \%$ \\
\hline & Journal of Business Venturing & 2 & 4 & $20.0 \%$ \\
\hline & Small Business Economics & 2 & 6 & $30.0 \%$ \\
\hline \multirow{14}{*}{ Zone B } & Emerging Markets Finance and Trade & 1 & 7 & $35.0 \%$ \\
\hline & European Management Review & 1 & 8 & $40.0 \%$ \\
\hline & Financial Management & 1 & 9 & $45.0 \%$ \\
\hline & $\begin{array}{c}\text { IEEE Transactions on Engineering } \\
\text { Management }\end{array}$ & 1 & 10 & $50.0 \%$ \\
\hline & $\begin{array}{c}\text { International Entrepreneurship } \\
\text { and Management }\end{array}$ & 1 & 11 & $55.0 \%$ \\
\hline & International Small Business Journal & 1 & 12 & $60.0 \%$ \\
\hline & Journal of Business Research & 1 & 13 & $65.0 \%$ \\
\hline & Journal of Financial Intermediation & 1 & 14 & $70.0 \%$ \\
\hline & Journal of Media Economics & 1 & 15 & $75.0 \%$ \\
\hline & $\begin{array}{l}\text { Journal of Multi-Criteria } \\
\text { Decision Analysis }\end{array}$ & 1 & 16 & $80.0 \%$ \\
\hline & Research Policy & 1 & 17 & $85.0 \%$ \\
\hline & Strategic Management Journal & 1 & 18 & $90.0 \%$ \\
\hline & $\begin{array}{l}\text { Technology Analysis \& } \\
\text { Strategic Management }\end{array}$ & 1 & 19 & $95.0 \%$ \\
\hline & Venture Capital & 1 & 20 & $100.0 \%$ \\
\hline
\end{tabular}

Table 6. The ten most cited papers.

\begin{tabular}{cccc}
\hline References & $\begin{array}{c}\text { Quantity of } \\
\text { citations }\end{array}$ & $\begin{array}{c}\text { Frequency of } \\
\text { citations } \%\end{array}$ & $\begin{array}{c}\text { Annual average } \\
\text { of citations }\end{array}$ \\
\hline Hsu (2007) & 256 & $46.8 \%$ & 17.07 \\
Zheng et al. (2010) & 53 & $9.7 \%$ & 4.42 \\
Ivanov and Xie (2010) & 53 & $9.7 \%$ & 4.42 \\
Block et al. (2014) & 47 & $8.6 \%$ & 5.88 \\
Wasserman (2017) & 39 & $7.1 \%$ & 7.80 \\
Hornuf and Neuenkirch (2017) & 23 & $4.2 \%$ & 4.60 \\
Joglekar and Levesque (2009) & 23 & $4.2 \%$ & 1.77 \\
Masulis and Nahata (2009) & 19 & $3.5 \%$ & 1.46 \\
Greenberg (2013) & 18 & $3.3 \%$ & 2.00 \\
Davila et al. (2015) & 16 & $2.9 \%$ & 2.29 \\
Total & 547 & $100.0 \%$ & \\
\hline
\end{tabular}




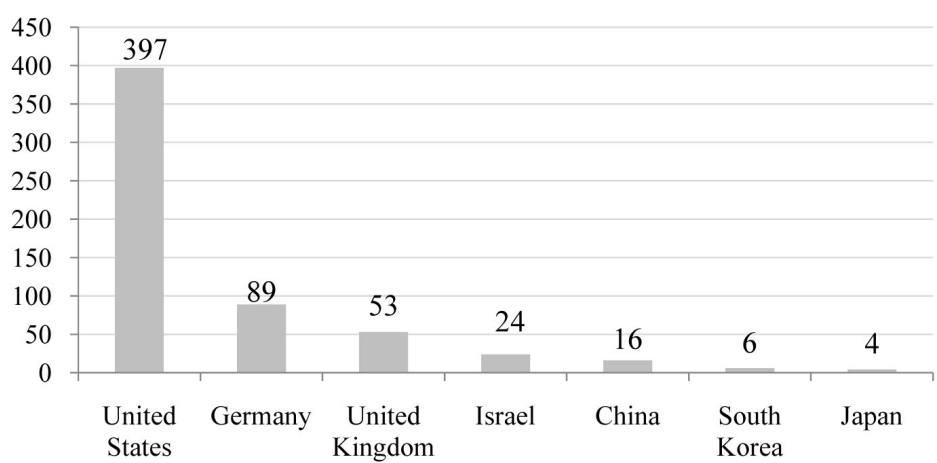

Figure 5. Frequency of citations of papers in the countries of the institutions with which the authors are associated.

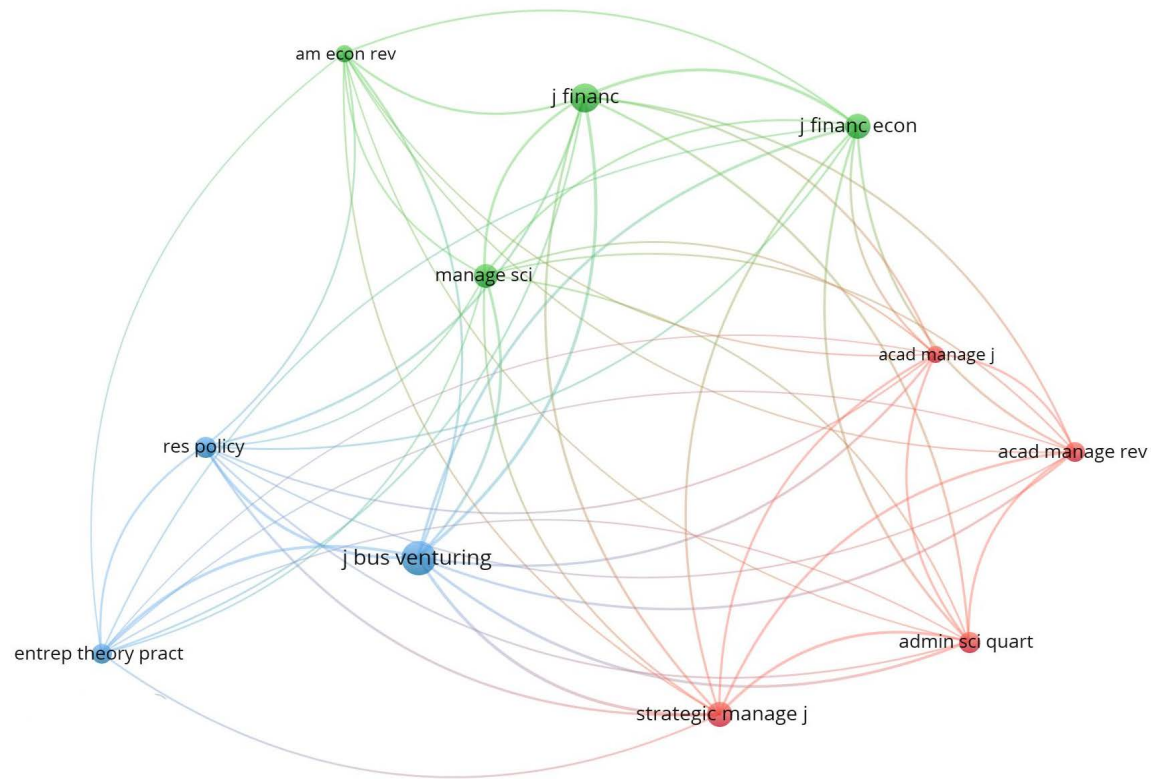

Figure 6. Co-citations map among journals. Source: VOSviewer. Note: The size of the nodes represents the relevance of the terms in the papers. The thickness of the lines means the bonding force between them. The colors indicate the number of groups.

equal in quantity to the performance of the others. This law is named as the inverse square law-see Equation (4).

$$
a_{n}=a_{1} / n^{2}, n=1,2,3
$$

In which:

$a_{n}=$ number of authors who published $n$ papers

$a_{1}=$ number of authors who published one paper

$n=$ number of papers published by author

For Equation (5), Chung and Cox (1990) clarify that the number of authors with a single published paper, according to Lotka's Law, would be:

$$
a_{1}=6 / \pi^{2}=0.6079=60.8 \%
$$

Thus, an author with two published papers should have a frequency of $15.2 \%$ 
$(0.6079 / 22)$. For an author with three published papers would be $6.8 \%(0.6079 / 32)$. Of the 44 papers in the final sample, it appears that there is a single paper for each author. This fact makes confirming the Lotka's Law impossible.

\subsection{Systematic Review}

The literature systematic review seeks to identify the knowledge gaps related to the theme of this study-main methods for valuating SUs. For this, in Step 6 of Item 3-Methodology, a matrix of (sub) categorization is defined-see Table 1. For each of the 20 papers in the final sample, there is the identification of up to 3 subcategories per category. Thus, the frequency count is made in relation to the total of the subcategories and not to the total of the 20 papers.

Figure 7 highlights the subcategories with greater and lesser frequency-those that have the potential to be prioritized in future research. In category 1 , the theme of SUs' valuation by venture capital funds $(\mathrm{A}-\mathrm{C})$ is the most highlighted in the final sample (60\%), with the opportunity to analyze other ways of funding entrepreneurial activities (B - E). As for the theories supporting the valuation of SUs, the greatest individual emphasis is given to signaling (A). Thus, other theories may be investigated-games (B), institutional, resource dependence and network (C), etc. With regard to the institutional theory, Berger and Kohn (2018) show that a country's legal system, its cultural environment and capacity for innovation play a relevant role in SUs' valuation by venture capital funds.

Concerning the research methods, category 3 indicates that $60 \%$ of the subcategories are related to econometric models (B). Another $20 \%$ refer to case studies (C). Only $10 \%$ mention the application of questionnaires complementing the econometric models (A - B). Dhochak and Doliya (2020) - when applying questionnaires in India-find that the entrepreneur's skills, entrepreneur's background, leadership qualities and size of his relationship network are relevant criteria in the valuation of SUs.

As far as the valuation methods are concerned, category 4 does not have combined subcategories. Thus, $40 \%$ of the papers adopt the relative valuation-multiples (B) - to valuate the SUs. The equity valuation (C) is considered in $25 \%$ of the studies. It shows that discounted cash flow (A) and real options (D) are still little explored methods in the valuation of these companies. Fujiwara (2014) states that the real options method is the most suitable for companies that focus on innovation, research and development and strategic partnerships-e.g.: biotechnology. Thus, traditional methods are applicable in SUs' valuation. The main difficulty for their implementation is to identify the appropriate inputs for each one of them.

This fact is clarified in category 5. Among the main inputs of the valuation models are the capacity for innovation and managerial/accounting information (A-E), representing $20 \%$ of the subcategories. Noteworthy is that the ability to transform resources into innovations (A) totals $50 \%$ of the subcategories, considering other inputs with lesser frequency-internal resources (B), external links 


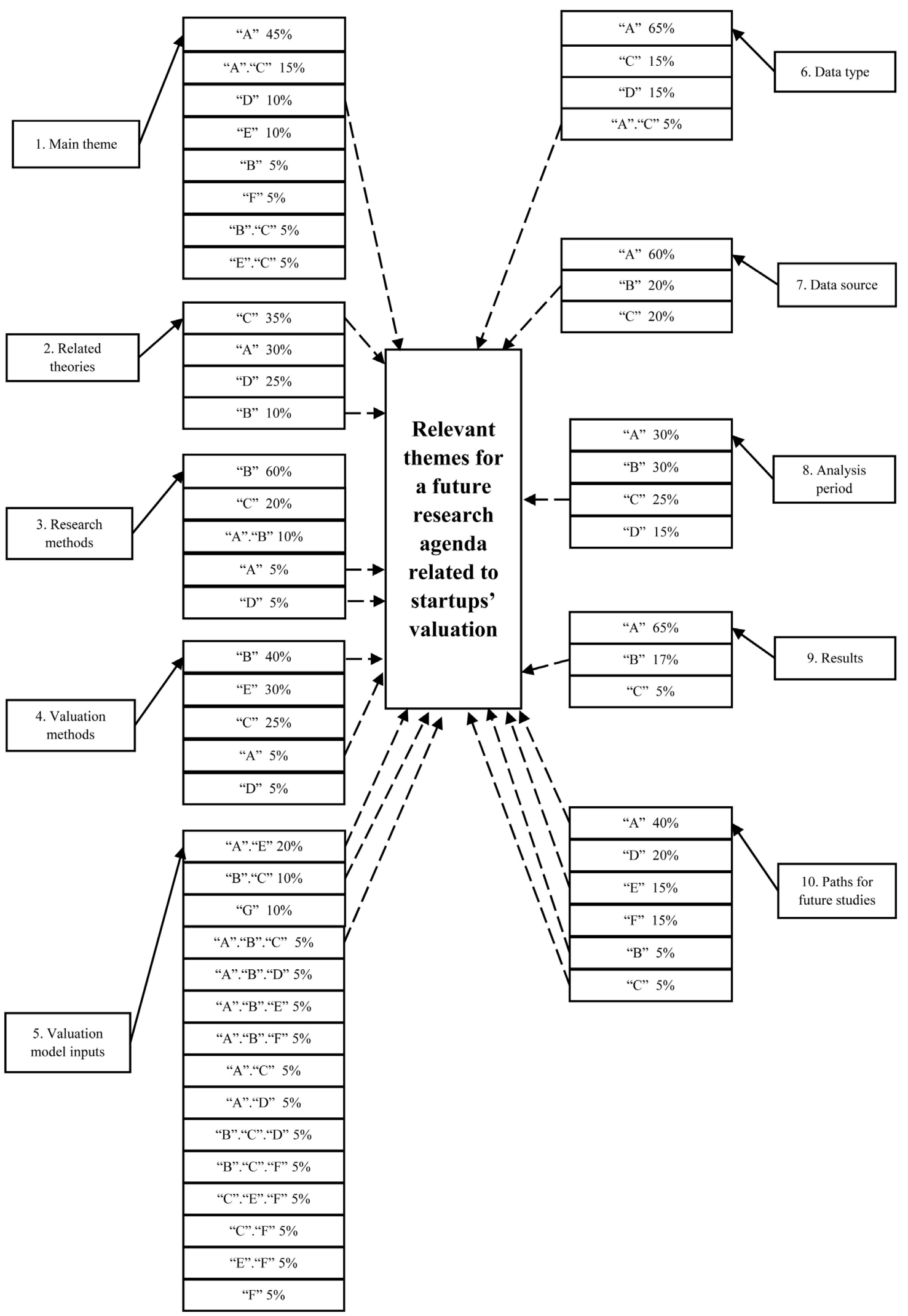

Figure 7. Analysis of (sub) categories to identify knowledge gaps. Note:

Subcategory with greater frequency in each category; $------\rightarrow$ Subcategory to be prioritized in future research agenda. 
(C) and competitive advantages (D). Another $10 \%$ refer to internal resources and external links (B C). For Zheng et al. (2010) and Zhai and Carrick (2019), the capacity for innovation generates knowledge, development of new products and it improves the companies' financial performance, besides attracting and maximizing the SUs' value. In the case of SUs in the high-tech sector, innovation is correlated with their long-term growth potential.

In turn, category 6 presents the types of data analyzed, depending on the stage of the SUs' evolution. They may be in an early stage or scaleup phase. In the former, they do not have an accounting data history, while in the latter, they do. This may be the reason why $60 \%$ of the subcategories consider the financial statements (A) as being the main data source for the studies in the final sample. Other less considered sources are the regulatory bodies (B) and questionnaires (C), corresponding to $15 \%$ of the subcategories each. For Gavious and Schwartz (2011), the role of accounting statements-in explaining the SUs' market value-is secondary, depending on the perception by investors about the time needed to generate profit. Thus, the growth in sales becomes more relevant, being considered as indicative of the feasibility and potential of the enterprise. Yet for Sievers et al. (2013), both accounting and non-financial information are relevant to explain the SU's pre-money valuation.

As for the data source, category 7 indicates that $60 \%$ (A) of the papers analyze companies from developed countries, with space for research about emerging countries (B). Regarding the analysis period, $60 \%$ of the studies (A-B) analyze the data up to 10 years. Thus, there is an opportunity for long-term investigations-over 10 years (C). The innovation character obtained in the research results in category 9 also stands out. $65 \%$ of the studies point to new perspectives (A), with the presentation of a new theory, variable, proxy or SUs' valuation method. The study by Hsu (2007) points out that the accumulation of human and social capital are measures of organizational performance, essential in valuating the SUs'risk and price. For Greenberg (2013), proxies such as brands and patents are positively related to software companies in the early stage phaseinitial pre-revenue stage, when the first round of investment capitalization occurs. In turn, Berger and Kohn (2018) show that the valuation of SUs is affected by the institutional environment in which they are inserted.

Finally, category 10 indicates paths for future studies or knowledge gapsaccording to the perspective by the authors of the 20 papers in the final sample. In $40 \%$ of the subcategories, the authors suggest the SUs' valuation at different stages of development (A)-e.g.: early stage, scaleup, etc. Another $20 \%$ indicate the examination of the effects of the organizational growth dynamism (D) on the SUs' value. The least mentioned themes are cultural differences (B) and valuation of intangibles (C). With regard of the stages of development, Zhai and Carrick (2019) suggest that SUs willing to be unicorns should analyze possible paths for the establishment of strategic alliances. Greenberg (2013) proposes an analysis of the effect of granting patents on the SUs' value-especially in their early 
stage phase. Zheng et al. (2010) stimulate the investigation of the dynamism associated with organizational growth, as well as the effect that different types of resources have over time. For Berger and Kohn (2018), new research must analyze how cultural and institutional distance may affect the valuation of SUs, from the perspective by VC companies.

In view of the above, this study highlights the following knowledge gaps to be investigated in future studies - related to the theme of SUs' valuation: 1) specific characteristics of companies located in emerging countries, considering their cultural differences and institutional/regulatory environment; 2) determinants that influence their value at different stages of maturity-early stage, scaleup, etc; 3) use of alternative variables to accounting statements-stage of development, market size, tax benefits, manager's experience, product or service differentiation, organizational growth, competitive advantages, relationship network, strategic partnerships, intellectual property, patents, etc; 4) adoption of unconventional valuation methods-First Chicago, Scorecard, Venture Capital, Berkus, etc; 5) analysis of game, institutional, resource and network dependence theories; 6) primary data through surveys and class associations.

\section{Conclusion}

SUs are companies having innovation and accelerated growth as their feature. Thus, their valuation process - at different stages-is a challenge for their investors. Another complexity in this process refers to the identification of the most appropriate variables and methods for measuring their value. This fact stems from the absence of historical accounting records and uncertainty about their future. Given the lack of research on this topic, this study performs a bibliometric analysis and literature systematic review on the valuation of SUs. As a result, there is the identification of knowledge gaps to be filled by a proposal for a future research agenda related to this theme.

The initial sample consists of 160 papers that-after adopting the exclusion criteria mentioned in item 3, Methodology-is reduced to 20 final studies, being obtained from the WoS database. The bibliometric analysis presents quantitative data through graphs, relationship maps and tables on the main dimensions and laws of bibliometrics, namely: keywords-Zipf's law (1949), journals-Bradford's law (1934) and authors-Lotka's law (1926). Such checks occur through the software RStudio, Biblioshiny, VOSviewer and Rank Words. In turn, the systematic review identifies the frequency of the (sub) categories defined for the final sample. Its verification allows the perception of what combinations of subcategories are feasible to future investigations.

As a result of the bibliometric analysis, the words performance, innovation and SUs are the most frequently used. The most highlighted journals in the final sample are: European Accounting Review, Journal of Business Venturing and Small Business Economics. As for the most cited paper, it is the one by Hsu (2007) with 256 citations, presenting an annual average of 17.07. The author 
empirically investigates the criteria that VC funds consider in their investment decision in SUs. Finally, it appears that there is a single article for each author, which prevents confirming Lotka's Law.

Concerning the systematic review, the analysis is done via the frequency identification of the subcategories described in Table 1, summarized in Figure 7. For SUs, the topic of identifying funding sources is urgent, considering the fact that they are companies with high uncertainty and risk levels. As for the theories that guide their valuation are the ones of signaling and of games. Another concern refers to the way of obtaining the types of data for inputs in the valuation models. The lack of historical accounting data induces the application of questionnaires and the use of alternative variables-stage of development, market size, tax benefits, manager's experience, etc. Among the valuation methods, the ones of multiples are highlighted. Regarding future paths for further research, the authors emphasize the analysis of determinants influencing their value at different stages of maturity-early stage, scaleup, etc., as well as the adoption of unconventional valuation methods-First Chicago, Scorecard, Venture Capital, Berkus, etc.

With regard of the limitations of this study, the results obtained are emphasized as being restricted to the selection criteria defined in item 3, Methodology, and to the papers made available by WoS. Thus, for the evolution of this research, the adoption of more specific criteria related to SUs is suggested, such as the analysis of different stages of operation-early stage, scaleup, etc.-and of specific segments of companies in industry 4.0-nanotechnology, neurotechnology, biotechnology, robotics, artificial intelligence and energy storage, etc.

\section{Conflicts of Interest}

The authors declare no conflicts of interest regarding the publication of this paper.

\section{References}

Amalian, A. W., \& Amalyan, N. D. (2018). Start-up First Term Sheet: Stumbling Blocks to Avoid. Biznes Inform, No. 1, 104-110. http://business-inform.net/export pdf/business-inform-2018-1 0-pages-104 110.pdf

Audretsch, D. B., \& Link, A. N. (2012). Valuing an Entrepreneurial Enterprise. Small Business Economics, 38, 139-145. https://doi.org/10.1007/s11187-011-9409-5

Baek, H. Y., \& Neymotin, F. (2016). International Involvement and Production Efficiency among Startup Firms. Global Economic Review, 45, 42-62. https://doi.org/10.1080/1226508X.2015.1084240

Becker, J. U., Clement, M., \& Nöth, M. (2016). Start-Ups, Incumbents, and the Effects of Takeover Competition. Journal of Business Research, 69, 5925-5933.

https://doi.org/10.1016/j.jbusres.2016.05.005

Berger, E., \& Köhn, A. (2018). Exploring the Differences in Early-Stage Start-up Valuation across Countries: An Institutional Perspective. International Entrepreneurship Management Journal, 16, 327-344. https://doi.org/10.1007/s11365-018-0534-3 
Block, J. H., De Vries, G., Schumann, J. H., \& Sandner, P. (2014). Trademarks and Venture Capital Valuation. Journal of Business Venturing, 29, 525-542. https://doi.org/10.1016/j.jbusvent.2013.07.006

Booth, A. D. (1967). A "Law" of Occurrences for Words of Low Frequency. Information and Control, 10, 386-393. https://doi.org/10.1016/S0019-9958(67)90201-X

Bradford, S. C. (1934). Sources of Information on Scientific Subjects. Engineering: An IIlustrated Weekly Journal, 137, 85-86.

Brookes, B. C. (1969). Bradford's Law and the Bibliography of Science. Nature, 224, $953-$ 956. https://doi.org/10.1038/224953a0

Chung, K. H., \& Cox, R. A. K. (1990). Patterns of Productivity in the Finance Literature: A Study of the Bibliometric Distributions. Journal of Finance, 45, 301-309. https://doi.org/10.1111/j.1540-6261.1990.tb05095.x

Davila, A., Foster, G., \& Jia, N. (2015). The Valuation of Management Control Systems in Start-Up Companies: International Field-Based Evidence. European Accounting Review, 24, 207-239. https://doi.org/10.1080/09638180.2014.965720

Dhochak, M., \& Doliya. P. (2020). Valuation of a Startup: Moving towards Strategic Approaches. Journal of Multi-Criteria Decision Analysis, 27, 39-49. https://doi.org/10.1002/mcda.1703

Festel, G., Wuermseher, M., \& Cattaneo, G. (2013). Valuation of Early-Stage High-Tech Start-Up Companies. International Journal of Business, 18, 216-231.

Fitza, M., \& Dean, T. J. (2016). How Much Do VCS and Underwriters Matter? A Comparative Investigation of Venture Capitalist and Underwriter Effects on IPO Underpricing. Venture Capital, 18, 95-114. https://doi.org/10.1080/13691066.2016.1123347

Fujikawa, T. (2014). Real Options Analysis on Strategic Partnerships of Biotechnological Start-Ups. Technology Analysis \& Strategic Management, 26, 617-638. https://doi.org/10.1080/09537325.2014.923834

Gavious, I., \& Schwartz, D. (2011). Market Valuations of Start-up Ventures around the Technology Bubble. International Small Business Journal, 29, 399-415. https://doi.org/10.1177/0266242610369750

Glaveckaitè, Ž. (2020). The Development Process of the Right Team in Early-Stage StartUps. Entrepreneurship and Sustainability Issues, 8, 1041-1063. https://doi.org/10.9770/jesi.2020.8.1(70)

Goffman, W. (1971). A Mathematical Method for Analyzing the Growth of a Scientific Discipline. Journal of the Association for Computing Machinery, 18, 173-185. https://doi.org/10.1145/321637.321640

Greenberg, G. (2013). Small Firms, Big Patents? Estimating Patent Value Using Data on Israeli Start-Ups' Financing Rounds. European Management Review, 10, 183-196. https://doi.org/10.1111/emre.12015

Hornuf, L., \& Neuenkirch, M. (2017). Pricing Shares in Equity Crowdfunding. Small Business Economics, 48, 795-811. https://doi.org/10.1007/s11187-016-9807-9

Hsu, D. H. (2007). Experienced Entrepreneurial Founders, Organizational Capital, and Venture Capital Funding. Research Policy, 36, 722-741. https://doi.org/10.1016/j.respol.2007.02.022

International Accounting Standards (IAS) (2004). IAS 38-Intangible Assets. International Accounting Standards. https://www.iasplus.com/en/standards/ias/ias38

International Financial Reporting Standards (IFRS) (2008). IFRS 3-Business Combinations. Fairfield, NJ: International Financial Reporting Standards. 
https://www.iasplus.com/en/standards/ifrs/ifrs3

Ivanov, V. I., \& Xie, F. (2010). Do Corporate Venture Capitalists Add Value to Start-Up Firms? Evidence from IPOs and Acquisitions of VC-Backed Companies. Financial Management, 39, 129-152. https://doi.org/10.1111/j.1755-053X.2009.01068.x

Joglekar, N. R., \& Lévesque, M. (2009). Marketing, R\&D, and Startup Valuation. IEEE Transactions on Engineering Management, 56, 229-242. https://doi.org/10.1109/TEM.2008.927827

Kleinert, S., \& Volkmann, C. (2019). Equity Crowdfunding and the Role of Investor Discussion Boards. Venture Capital, 21, 327-352. https://doi.org/10.1080/13691066.2019.1569853

Laitinen, E. K. (2019). Discounted Cash Flow (DCF) as a Measure of Startup Financial Success. Theoretical Economics Letters, 9, 2997-3020. https://doi.org/10.4236/tel.2019.98185

Lotka, A. J. (1926). The Frequency Distribution of Scientific Productivity. Journal of the Washington Academy of Sciences, 16, 317-323.

Masulis, R. W., \& Nahata, R. (2009). Financial Contracting with Strategic Investors: Evidence from Corporate Venture Capital Backed IPOs. Journal of Financial Intermediation, 18, 599-631. https://doi.org/10.1016/j.jfi.2009.06.001

Mirzanti, I. R., Sinaga, E. E. M., \& Soekarno, S. (2019). Determinant Factors in Digital Start-up Valuation for Agro Seed Funding. International Journal of Agricultural Resources, Governance and Ecology, 15, 338-357. https://doi.org/10.1504/IJARGE.2019.104202

Pao, M. L. (1978). Automatic Text Analysis Based on Transition Phenomena of Word Occurrences. Journal of the American Society for Information Science, 29, 121-124. https://doi.org/10.1002/asi.4630290303

Sievers, S., Mokwa, C. F., \& Keienburg, G. (2013). The Relevance of Financial versus NonFinancial Information for the Valuation of Venture Capital-Backed Firms. European Accounting Review, 22, 467-511. https://doi.org/10.1080/09638180.2012.741051

Vaidyanathan, R., Vaidyanathan, V., \& Wadhwa, V. (2019). Exploring Entrepreneurs' Perceptions of Venture Capitalists' Added Value. Journal of Macromarketing, 39, 447462. https://doi.org/10.1177/0276146719884610

Wasserman, N. (2017). The Throne vs. the Kingdom: Founder Control and Value Creation in Startups. Strategic Management Journal, 38, 255-277.

https://doi.org/10.1002/smj.2478

World Bank (2019). New Country Classifications by Income Level: 2019-2020. https://blogs.worldbank.org/opendata/new-country-classifications-income-level-2019$\underline{2020}$

Yoo, C., Yang, D., Kim, H., \& Heo, E. (2012). Key Value Drivers of Startup Companies in the New Media Industry-The Case of Online Games in Korea. Journal of Media Economics, 25, 244-260. https://doi.org/10.1080/08997764.2012.729546

Zacharakis, A., Erikson, T., \& George, B. (2010). Conflict between the VC and Entrepreneur: The Entrepreneur's Perspective. Venture Capital, 12, 109-126.

https://doi.org/10.1080/13691061003771663

Zhai, J. \& Carrick, J. (2019). The Rise of the Chinese Unicorn: An Exploratory Study of Unicorn Companies in China. Emerging Markets Finance and Trade, 55, 3371-3385. https://doi.org/10.1080/1540496X.2019.1610877

Zheng, Y., Liu, J., \& George, G. (2010). The Dynamic Impact of Innovative Capability and Inter-Firm Network on Firm Valuation: A Longitudinal Study of Biotechnology Start- 
Ups. Journal of Business Venturing, 25, 593-609.

https://doi.org/10.1016/j.jbusvent.2009.02.001

Zipf, G. K. (1949). Human Behavior and the Principle of Least Effort: An Introduction to Human Ecology. Cambridge, MA: Addison-Wesley Press. 